\title{
Studies Concerning the Economic Efficiency and Quality of the Vegetal Sausages
}

\author{
Claudiu-Dan SĂLĂGEAN, Dorin ŢIBULCĂ \\ University of Agricultural Sciences and Veterinary Medicine, Faculty of Food Science and Technology, 3-5 \\ Mănăştur Street, 400372 Cluj-Napoca, Romania, salageancd@yahoo.com
}

Bulletin UASVM Food Science and Technology 71(1) / 2014

ISSN-L 2344-2344; Print ISSN 2344-2344; Electronic ISSN 2344-5300

\begin{abstract}
The purpose of performed research aimed to establish the influence of protein supplements on the quality and economic efficiency in the processing of a certain semi-smoked sausage assortment using two experimental processing technologies: with $3 \%$ soy protein derivatives as supplements and $100 \%$ soy protein derivatives as vegetal raw materials. The results revealed that, from an economical point of view, the vegetal processing technology (with exclusively vegetal raw materials) was more efficiently than the supplemented processing technology (with protein derivatives as supplements) and from qualitatively point of view, the obtained values have been in accordance with the in force STAS-es.
\end{abstract}

Keywords: raw material, soy protein supplements, processing technology, supplemented sausage, vegetal sausage, economical analysis, quality, physical-chemical quality indicators.

Introduction. Soy proteins are no longer "filling" substances or auxiliary. Present soy protein derivatives become raw materials for meat products, which really improve the aspect, texture and freshness of these products, reducing in the same time fat and cholesterol. The use of soy protein derivatives for the processing of meat products has spread on the national and international scale due to their technique-functional, nutritional and economical advantages (Banu, C. et al., 1997).

Materials and methods. Our research followed the influence of protein supplements on the quality and the economic efficiency in the processing of a certain semi-smoked sausage assortment, in the following two experimental variants:

variant I - using supplemented processing technology, with animal raw material (beef, pork for processing and animal fat) in addition with $25 \%$ animal protein supplements (pork skin emulsion) and $3 \%$ vegetal protein supplements (soy protein isolate)

variant II - using exclusively vegetal processing technology, in which the animal raw material (meat, fat) has been integrally replaced with vegetal protein supplements - soy protein isolate (75\%) and vegetal oil (25\%)

The both technologies have been used a processing recipe and the results have been analysed from qualitatively (physical-chemical) and economically point of view.

Results and discussions. The results of experiments are shown in Table 1. The comparative economical analysis revealed higher values concerning the profit (euro) in the vegetal processing technology compared with the supplemented processing technology and values of the physical-chemical quality indicators in accordance with the in force STAS-es (in both experimental variants).

Conclusion. The comparative economical and qualitatively analyses of the experimental results obtained by testing the two technologies highlighted that, from an economical point of view, the vegetal technology (with exclusively 
Table 1. Comparative technological, economical and quality analysis of the experimented recipes in both of the experimental variants

\begin{tabular}{|c|c|c|c|}
\hline \multirow{2}{*}{ No. } & \multirow{2}{*}{ Indicators } & \multicolumn{2}{|c|}{ Variant } \\
\hline & & I & II \\
\hline \multicolumn{4}{|c|}{ Economical indicators } \\
\hline 1. & Losses (\% composition) & 18.5 & 9 \\
\hline 2. & Specific consumption $(\mathrm{kg} / \mathrm{kg})$ & 0.75 & 0.40 \\
\hline 3. & Expenses / 100 kg raw material (euro) & 255 & 340 \\
\hline 4. & Incomes / 100 kg raw material (euro) & 275 & 395 \\
\hline \multirow{2}{*}{5.} & / 100 kg raw material & 20 & 55 \\
\hline & / Incomes (\%) & 7.27 & 13.92 \\
\hline \multicolumn{4}{|c|}{ Physical-chemical indicators (Normative values - Ord. 560/2006 / Obtained medium values) } \\
\hline \multirow{2}{*}{1.} & \multirow{2}{*}{ Water $(\mathrm{g} \%)$} & Max 63 & Max 75 \\
\hline & & 58.50 & 72.48 \\
\hline \multirow{2}{*}{2.} & \multirow{2}{*}{ Fat $(g \%)$} & Max 32 & Max 10 \\
\hline & & 25.20 & 9.84 \\
\hline \multirow{2}{*}{3.} & \multirow{2}{*}{ Total protein substances, $\mathrm{g} \%$} & Min 12 & Min 10 \\
\hline & & 13.51 & 15.95 \\
\hline \multirow{2}{*}{4.} & \multirow{2}{*}{ Easily hydrolysable Nitrogen ( $\left.\mathrm{mg} \mathrm{NH}_{3} / 100 \mathrm{~g}\right)$} & Max 45 & - \\
\hline & & 15.83 & - \\
\hline \multirow{2}{*}{5.} & \multirow{2}{*}{$\mathrm{NaCl}(\mathrm{g} \%)$} & Max 3 & Max 3 \\
\hline & & 2.17 & 1.73 \\
\hline \multirow{2}{*}{6.} & \multirow{2}{*}{$\mathrm{NaNO}_{2}(\mathrm{mg} / 100 \mathrm{~g})$} & $\operatorname{Max} 10$ & absent \\
\hline & & 2.32 & absent \\
\hline \multirow{2}{*}{7.} & \multirow{2}{*}{ Collagen / proteins (\%) } & Max 30 & - \\
\hline & & 17.41 & - \\
\hline \multirow{2}{*}{8.} & \multirow{2}{*}{$\mathrm{P}_{2} \mathrm{O}_{5}(\mathrm{mg} / \mathrm{kg})$} & Max 5000 & absent \\
\hline & & 3964.87 & absent \\
\hline
\end{tabular}

vegetal raw materials) was more efficiently than the supplemented processing technology (with protein derivatives as supplements) and from qualitatively point of view, the obtained values were in accordance with the in force STAS-es.

The advantages of the usage of the vegetal protein derivatives in the processing of meat products (as raw materials, exclusively vegetal) consist in elimination of the variation in the quality of animal raw materials, a lower content in cholesterol, calories, fats of the finished products therefore being recommended as dietetic food (hypoglucidic and hypocaloric), with a good impact over the human health.

These vegetal products assured a higher economical efficiency through minimizing the technological losses and specific consumption of the raw materials with 25 up to $30 \%$ which is reflected in the final cost of the products (it was reduced with $20-25 \%$ ).
The most important problem of the vegetal processing technology is the acceptability of these vegetal products by the consumers (especially regarding the taste). Taking into consideration the technological-functional, nutritional and economical advantages of using the vegetal derivatives in the processing of the meat products it comes as a compulsory condition for obtaining economical and qualitative performance.

\section{REFERENCES}

1. Banu, C. et al. (1997). Procesarea industrială a cărnii, Editura Tehnică, București, 351-364.

2. Sălăgean, C.D. (2006). Researches concerning the optimization of using protein derivates in the processing of meat products in casings and the quality of the obtained products, PhD Thesis, USAMV Cluj-Napoca, p. 1-296.

3. ***Ordinul $560 / 2006$ pentru aprobarea Normelor cu privire la comercializarea produselor din carne. 